\title{
Stewardship Ecosystem Services Study: Carbon Stores on Florida Forest Stewardship Program Lands ${ }^{1}$
}

\author{
Nilesh Timilsina, Francisco J. Escobedo, Alison E. Adams, and Sonia Delphin²
}

Nonindustrial private forestlands in Florida provide many environmental benefits, or ecosystem services. Ecosystem services are benefits from nature that are directly enjoyed, consumed, or used by humans (Escobedo et al. 2012). Examples of benefits include water quality improvement or protection, recreation, biodiversity, and even timber (also referred to as an ecosystem good). Another benefit from forests that is gaining interest is their ability to store carbon (C) through the photosynthetic capture of carbon dioxide, a greenhouse gas, in tree, plant, and soil biomass. The carbon dioxide that is stored over the life of a forest, called carbon stocks, is not only important for mitigating greenhouse gas contributions to climate change, but it can also be valued in several markets and incorporated into environmental policy instruments (Yonavjak et al. 2011; http://pdf.wri.org/ forests_for_carbon.pdf).

The State of Florida and the USDA Forest Service recognize the important role that forests play in our economy and in maintaining environmental quality and wildlife habitat. In particular, the Florida Forest Stewardship Program (FSP) presents an opportunity for forest landowners to manage their forests for multiple uses (http://www.floridaforestservice.com/forest_management/cfa_steward_index.html). The FSP promotes forest conservation, and encourages landowners to promote and maintain the many ecosystem services their land provides. In 2012 alone there were approximately 2700 private forests enrolled in the FSP
(Escobedo et al. 2012). This publication provides information on the amount and value of $\mathrm{C}$ stored, or $C$ stocks in Florida's FSP forests and adjacent non-FSP forests, as well as an overview of carbon dioxide accounting programs that provide incentives for storing carbon via forest management. This information can be used by land owners for promoting the value provided by programs like the FSP and can help land managers, policy makers, and the public at large recognize the importance of conserving working forests.

\section{How were Carbon Stocks on Forest Lands Estimated?}

The estimates in this publication are based on a study that quantified the ecosystem services and value provided by properties enrolled in the FSP (Escobedo and Timilsina 2012; Timilsina et al. 2013a; Kreye et al. 2013). The Florida FSP properties that were analyzed comprised 99,800 acres and had existing management plans and available property boundary data. The Florida Forest Service provided the FSP property data, and carbon stock data for 2002-2007 was obtained from the US Department of Agriculture's (USDA) Forest Inventory and Analysis (FIA) program (http:// srsfia2.fs.fed.us/ ). Please refer to Timilsina (2012) and Timilsina et al. (2013a) for details on data and methods.

1. This document is FOR316, one of a series of the School of Forest Resources and Conservation, UF/IFAS EXtension. Original publication date October 2013. Visit the EDIS website at http://edis.ifas.ufl.edu.

2. Nilesh Timilsina, assistant professor, University of Wisconsin Stevens Point; Francisco J. Escobedo, associate professor, School of Forest Resources and Conservation; Alison E. Adams, graduate student, Department of Sociology; and Sonia Delphin, graduate student, School of Forest Resources and Conservation; UF/IFAS Extension, Gainesville, FL 32611.

The Institute of Food and Agricultural Sciences (IFAS) is an Equal Opportunity Institution authorized to provide research, educational information and other services only to individuals and institutions that function with non-discrimination with respect to race, creed, color, religion, age, disability, sex, sexual orientation, marital status, national origin, political opinions or affiliations. For more information on obtaining other UF/IFAS Extension publications, contact your county's UF/IFAS Extension office. 
Although the FIA is the most comprehensive national forest inventory system for the United States, specific FIA plot locations on private properties often are deliberately not made available to preserve the privacy of property owners. However, for this study the USDA's Forest Service provided field data for all Florida FSP properties with FIA plots within their boundaries and also for non-FSP properties within a one mile buffer around each FSP property (Personal communication with Samuel Lambert, USDA Forest Service, FIA Program, 2012). In total, there were 43 FIA plots on FSP properties and 489 non-FSP FIA plots within the one-mile buffer. Using the $\mathrm{C}$ pool data provided by the FIA, four types of C stocks, or pools, were calculated: aboveground, belowground, dead $\mathrm{C}$, and soil organic C (Table 1; Timilsina et al. 2013a). Carbon stocks were estimated for the four FIA regions in Florida (northeast, northwest, central, and south) and by forest types. See Timilsina et al. (2013a), for the locations of these $\mathrm{C}$ hotspots (i.e. forested areas with high $\mathrm{C}$ densities) Table 1. Carbon pool types in the USDA Forest Service Forest Inventory and Analysis Database

\begin{tabular}{|l|l|}
\hline Carbon Pools (Mg C/ha) & \multicolumn{1}{c|}{ Description } \\
\hline Aboveground & $\begin{array}{l}\text { Sum of aboveground tree and } \\
\text { understory carbon }\end{array}$ \\
\hline Belowground & $\begin{array}{l}\text { Sum of belowground tree and } \\
\text { understory carbon }\end{array}$ \\
\hline Dead C & $\begin{array}{l}\text { Sum of carbon in down and dead tree, } \\
\text { litter, and standing dead trees }\end{array}$ \\
\hline Soil organic C & $\begin{array}{l}\text { Soil organic carbon to a depth of 1 } \\
\text { meter }\end{array}$ \\
\hline Total C & $\begin{array}{l}\text { Sum of aboveground, belowground, } \\
\text { carbon dead, and soil organic carbon } \\
\text { pools }\end{array}$ \\
\hline
\end{tabular}

Note: $\mathrm{Mg} \mathrm{C} / \mathrm{ha}=$ Metric tons of carbon per hectare

in Florida. There were no FIA plots on FSP properties in south Florida, therefore, $\mathrm{C}$ stock estimates for FSPs are not reported.

\section{How Much Carbon is Stored in Forest Stewardship Program and Adjacent Lands?}

Timilsina (2012) found that average total C stocks in Florida's FSP lands was 153 to $166 \mathrm{Mg}$ C/ha and 138 to 190 $\mathrm{Mg} \mathrm{C} / \mathrm{ha}$ in adjacent non-FSP forests (Table 2). The average aboveground $\mathrm{C}$ stock for FSP properties ranged from 28 $\mathrm{Mg} \mathrm{C} /$ ha in Northeast Florida to $42 \mathrm{Mg}$ C/ha in Central Florida (Table 2). In general, FSP properties stored more $\mathrm{C}$ in all $\mathrm{C}$ pools as compared to non-FSPs, but results were not statistically different. The inability to find statistical differences could be due to the small sample size of FIA plots located on FSP properties. Nonetheless, the study's estimates were within the range of other forest $\mathrm{C}$ stock estimates for the southeastern United States. Please refer to Timilsina (2012) for details on results for the different carbon pools and Timilsina et al. (2013a) for forest C stock estimates from other studies.

\section{Carbon Stocks in Different Forest Types}

Mixed upland hardwood forests in northwestern Florida and slash pine forests in northeastern Florida had the highest aboveground C stocks found on FSP lands. For specific details and results see Timilsina 2012. Average total C was the highest in oak gum-and-cypress forests in northwestern and central Florida FSPs; but slash pine had the highest aboveground C in FSP lands in northeast Florida (Table 3).

\section{What is the Economic Value of Carbon Stocks on Florida's FSP lands?}

The total economic value of carbon on FSP properties was estimated based on prices provided by PointCarbon (http:// www.pointcarbon.com/). Overall, the average value of carbon stocks on FSP and adjacent lands across Florida's different regions, range from $\$ 5$ to $\$ 40$ per metric ton $(\mathrm{Mg}$ C) (or $\$ 1.36$ to $\$ 10.19$ per ton of carbon dioxide equivalent [CO2e]) through 2020 (Point Carbon 2010). Based on an assumed average value of $\$ 19$ per $\mathrm{Mg} \mathrm{C}$, the average dollar value per hectare of carbon stocks on FSPs was $\$ 3,154$ in northwestern Florida, \$2,907 for northeastern Florida, and $\$ 3,097$ for central Florida and $\$ 3,610$ for adjacent non-FSPs in southern Florida (Table 4). When accounting for the amount of FSP acreage in each FIA region (Table 5), the total-geographically weighted average-value of carbon stocks on FSP properties is approximately $\$ 300$ million dollars. This value was estimated by multiplying average economic value in dollars per hectare, assuming $\$ 19$ per Mg C, times the total of enrolled and active 2010 FSP hectares in each Florida region (Table 5). For a detailed description of methods and minimum and maximum economic values, see Timilsina (2012).

Overall, the expected average value per hectare of C stocks on FSP properties can range from $\$ 2,907$ to $\$ 3,610$. These values exceed the $\sim \$ 1,000$ average value reported by Moore et al. (2011) for private forests in Georgia. The total value of carbon stored in FSP properties of $\$ 300$ million is approximately four times the average value of $\mathrm{C}$ credits 
landowners would receive annually if all pine plantations in Florida were managed with moderate intensity (Mulkey et al. 2008).

\section{Forest Management and Policy Implications}

Increased forest $\mathrm{C}$ stocks are generally associated with large, old, dense tree stands, which also have structural characteristics that tend to affect other ecosystem services provided by forests, such as certain recreation opportunities or water yield (Timilsina et al. 2013b). However, with estimates of the value provided by carbon stocks, timber and other ecosystem services, as well as information on specific forest structure and management characteristics, forest landowners can make more informed decisions when implementing and developing multiple use management activities and objectives. See Timilsina et al. (2013a and 2013b) for relevant Florida forest structure and management characteristics that affect, or drive, forest carbon stocks and understory plant species diversity in Florida. Escobedo and Timilsina (2012) and Kreye et al. (2013) also list other ecosystem service values for water, wildlife, and timber related ecosystem services. As this publication and these other studies show, conserving working forests not only provides for timber and wildlife habitat, but indeed can also increase carbon sequestration and potential income from various ecosystem services.

Knowledge of the economic value and quantity of the $\mathrm{C}$ stocks in different regions and forest types in Florida is also useful for land owners since this information can be used to promote landowner participation in existing carbon markets (Charnley et al. 2010). Although no formalized carbon markets currently exist in Florida for carbon dioxide sequestration offsets, several voluntary carbon markets exist or are being developed (Yonavjak et al. 2011). Examples of $\mathrm{C}$ offset programs that exist for land owners to engage in voluntary carbon markets include:

- Climate Action Reserve (CAR; http://www.climateactionreserve.org/resources/faqs/),

- American Carbon Registry (ACR; http://americancarbonregistry.org/carbon-registry),

- Voluntary Carbon Standard (VCS, http://v-c-s.org/ develop-project).

These voluntary markets are programs that certify carbon offsets and recognize activities such as afforestation and reforestation of lands and improvement of forest management activities. Currently, some forestry projects in Alabama,
Georgia and South Carolina are registered under CAR for improved forest management and avoidance of conversion to other land uses (https://thereserve2.apx.com/myModule/ $\mathrm{rpt} / \mathrm{myrpt}$.asp). Florida landowners can opt for one of these carbon markets such as the VCS. Specific carbon accounting standards and protocols, requirements, technical details, and payment opportunities and mechanisms can be found in the CAR, ACR, and VCS websites above and in Yonavjak et al. (2011).

In conclusion, land managers and landowners can use the information in this publication not only to approximate carbon stocks on their lands, but also to understand the economic potential of their forests based on the latest available information. Similarly, policy makers can use the information to promote the benefits of multiple-use forest management objectives and conservation programs such as Florida's FSP. Finally, the estimates provided in this publication can be used to encourage landowners to conserve Florida’s working forests.

\section{Literature Cited}

Charnley, S., D. Diaz and H. Gosnell. 2010. Mitigating Climate Change through Small-Scale Forestry in the USA: Opportunities and Challenges. Small-Scale Forestry 9: 445-462.

Escobedo F. E., and N. Timilsina (Editors). 2012. Stewardship Ecosystem Services Survey Project. Gainesville, FL: University of Florida. Available at http://www.sfrc.ufl.edu/ cfeor/SESS.html

Kreye, M., F. J. Escobedo, D. C. Adams, T. Stein, and T. Borisova. 2013. Valuing the Ecosystem Services of Florida's Forest Conservation Programs: The Economic Benefits of Protecting Water Quality. University of Florida- IFAS, EDIS, FOR 309 https://edis.ifas.ufl.edu/fr377

Moore, R., T. Williams, E. Rodriguez, and J. H. Cymmerman. 2011. Quantifying the Value of Non-Timber Ecosystem Services from Georgia's Private Forests. Final Report submitted to the Georgia Forestry Foundation. http://www. warnell.uga.edu/news/wp-content/uploads/2011/02/FinalReport-1-24-11.pdf

Mulkey, S., J. Alavalapati, A. Hodges, A. C. Wilkie, and S. Grunwald. 2008. Opportunities for Greenhouse Gas Reduction through Forestry and Agriculture in Florida. School of Natural Resources and Environment, University of Florida, Gainesville, FL. http://snre.ufl.edu/research/greenhouse. htm 
Timilsina, N. 2012. Carbon Stocks on Forest Stewardship Program and Adjacent Lands Pg 69-78: In Escobedo F. E. and N. Timilsina (Eds.). Stewardship Ecosystem Services Survey Project. Gainesville, FL: University of Florida. Available at http://www.sfrc.ufl.edu/cfeor/SESS.html

Timilsina, N., F. Escobedo, W. Cropper, A. Abd-Elrahman, T. Brandeis, S. Delphin-Perez, and S. Lambert. 2013a. A framework for identifying carbon hotspots and forest management drivers. Journal of Environmental Management, 114: 293-302.

Timilsina, N., W. P. Cropper, Jr., F. J. Escobedo, and J. M. T. Lima. 2013b. Predicting understory species richness from stand and management characteristics using regression trees. Forests, 4:122-136. http://www.mdpi. com/1999-4907/4/1/122

Yonavjak, L., P. Swedeen, and J. Talberth. 2011. Forests for Carbon: Exploring Forest Carbon Offsets in the U.S. South. World Resources Institute Issue Brief 6. 20p. http://pdf.wri. org/forests_for_carbon.pdf 
Table 2. Carbon stocks (Mg C/ha) for Florida Forest Stewardship Program (FSP) properties and adjacent forests within 1 mile (nonforest stewardship) according to USDA Forest Inventory and Analysis (FIA) Florida regions. Note: $\mathrm{Mg} \mathrm{C} / \mathrm{ha}=$ Metric tons of carbon per hectare.

\begin{tabular}{|c|c|c|c|c|c|c|c|}
\hline \multirow[t]{2}{*}{ Carbon Pool } & \multirow{2}{*}{$\begin{array}{l}\text { Florida FIA } \\
\text { Regions }\end{array}$} & \multicolumn{3}{|c|}{ Forest Stewardship Properties } & \multicolumn{3}{|c|}{ Non- Forest Stewardship Properties } \\
\hline & & Mean & Min & Max & Mean & Min & Max \\
\hline \multirow[t]{4}{*}{ Aboveground } & Northwestern & 33 & 8 & 100 & 28 & 1 & 133 \\
\hline & Northeastern & 28 & 4 & 94 & 31 & 1 & 147 \\
\hline & Central & 42 & 8 & 76 & 44 & 4 & 68 \\
\hline & Southern & NA & NA & NA & 24.5 & 6 & 43 \\
\hline \multirow[t]{4}{*}{ Total carbon } & Northwestern & 166 & 104 & 266 & 138 & 32 & 362 \\
\hline & Northeastern & 153 & 116 & 245 & 143 & 17 & 378 \\
\hline & Central & 163 & 89 & 237 & 176 & 38 & 308 \\
\hline & Southern & NA & NA & NA & 190 & 115 & 265 \\
\hline
\end{tabular}

Table 3. Average total carbon stocks (Mg C/ha) for different forest types on Florida Forest Stewardship Program (FSP) and nonForest Stewardship Program (Non-FSP) properties according to USDA Forest Inventory and Analysis regions.

\begin{tabular}{|l|c|c|c|c|c|c|c|c|}
\hline \multirow{2}{*}{ Forest Types } & \multicolumn{2}{|c|}{ Northwestern } & \multicolumn{2}{|c|}{ Northeastern } & \multicolumn{2}{c|}{ Central } & \multicolumn{2}{c|}{ Southern } \\
\hline & FSP & Non-FSP & FSP & Non-FSP & FSP & Non-FSP & FSP & Non-FSP \\
\hline Longleaf pine & NA & 154 & 139 & 129 & 163 & NA & NA & NA \\
\hline $\begin{array}{l}\text { Mixed upland } \\
\text { hardwood }\end{array}$ & 135 & 78 & 120 & 87 & NA & 142 & NA & 191 \\
\hline $\begin{array}{l}\text { Oak gum } \\
\text { cypress }\end{array}$ & 216 & 246 & 203 & 263 & NA & 253 & NA & NA \\
\hline Oak hickory & NA & 73 & 64 & 74 & NA & 141 & NA & NA \\
\hline $\begin{array}{l}\text { Other pine } \\
\text { hardwood }\end{array}$ & 124 & 113 & 116 & 120 & NA & NA & NA & NA \\
\hline \begin{tabular}{l} 
Slash pine \\
\hline NA=Not available because forest type did not occur on FIA plots in this region.
\end{tabular} & 172 & 160 & 221 & 168 & NA & NA & NA & NA \\
\hline
\end{tabular}

Table 4. The average economic value of carbon stocks per hectare in Florida's Forest Stewardship (FSP) and adjacent non-ForestStewardship lands in Florida's Forest Inventory and Analysis (FIA) regions. Note: NA = No available data.

\begin{tabular}{|l|l|l|}
\hline \multicolumn{1}{|c|}{ FIA Region } & \multicolumn{1}{|c|}{$\begin{array}{c}\text { FSP Total Carbon Value } \\
\text { (US\$/ha) }\end{array}$} & $\begin{array}{c}\text { Non-FSP Total Carbon } \\
\text { Value (US\$/ha) }\end{array}$ \\
\hline Northeastern & 2,907 & 2,717 \\
\hline Northwestern & 3,154 & 2,622 \\
\hline Central & 3,097 & 3,344 \\
\hline Southern & NA & 3,610 \\
\hline
\end{tabular}

Table 5. Total economic value of carbon stocks on Florida's Forest Stewardship Program (FSP) lands in each Florida Forest Inventory and Analysis (FIA) region. Note: Only FSP properties with available spatial data were analyzed; estimates were rounded off from values in Table 4.

\begin{tabular}{|l|l|l|l|}
\hline \multicolumn{1}{|c|}{ FIA Region } & \multicolumn{1}{|c|}{$\begin{array}{c}\text { Total FSP Area } \\
\text { (ha) }\end{array}$} & \multicolumn{1}{|c|}{$\begin{array}{c}\text { Average Value } \\
\text { (\$ per ha) }\end{array}$} & \multicolumn{1}{c|}{$\begin{array}{c}\text { Total Value } \\
(\mathbf{\$})\end{array}$} \\
\hline Northeastern & 55,695 & $\$ 2,900$ & $\$ 161,905,370$ \\
\hline Northwestern & 32,562 & $\$ 3,150$ & $\$ 102,700,550$ \\
\hline Central & 8,985 & $\$ 3,100$ & $\$ 27,826,550$ \\
\hline Southern & 2,572 & $\$ 3,600^{*}$ & $\$ 9,284,900$ \\
\hline State-wide & \multicolumn{2}{|l}{} \\
\hline *Non- FSP average C stock value used for this estimate. & $\$ 302,000,000$ \\
\hline
\end{tabular}

